\title{
Aktivitas Enzim Selulase Kasar dari Isolat Bakteri Larva Cossus cossus dalam Hidrolisis Jerami Padi
}

\author{
Maswati Baharuddin ${ }^{1}$, Abdul Rauf Patong ${ }^{2}$, Ahyar Ahmad ${ }^{2}$, Nursiah La Nafie ${ }^{2}$ \\ ${ }^{1}$ Jurusan Kimia Fakultas Sains dan Teknologi, UIN Makassar \\ ${ }^{2}$ Jurusan Kimia FMIPA, Universitas Hasanuddin \\ Jl. Perintis Kemerdekaan Km 10 Tamalanrea, Makassar Sulawesi Selatan, Indonesia 90245 \\ *Email: bmaswati@gmail.com
}

\begin{abstract}
Abstrak
Limbah Industri dan pertanian yang mengandung selulosa mempunyai potensi sebagai bahan bakar alternatif terutama jerami padi. Penelitian ini dilakukan dengan melakukan uji hidrolisis isolat CC1 dan CC4 bakteri dari usus larva Cossus cossus pemakan kayu dengan menggunakan lignoselulosa dan selulosa jerami padi yang telah di hilangkan ligninnya dengan cara kimia dan jerami padi yang belum diproses. Pengukuran aktivitas enzim selulase menggunakan spektrofotometer UVVIS pada suhu dan $\mathrm{pH}$ optimum yang telah ditentukan sebelumnya. Dengan menggunkan metode Nelson Somoghy didapatkan aktivitas tertinggi enzim selulase dalam menghidrolisis substrat yakni pada serbuk selulosa dengan aktivitas optimum isolat CC4 pada $\mathrm{pH} 4$ sebesar $2.775 \times 10^{-2} \mathrm{U} / \mathrm{mL}$ sedangkan pada isolat CC2 aktivitas enzim $4.359 \times 10^{-2} \mathrm{U} / \mathrm{mL}$, hal ini karena hidrolisis yang terjadi secara enzimatik pada substrat selulosa dengan enzim selulase akan menguraikan selulosa menjadi bentuk yang sederhana yakni glukosa.
\end{abstract}

Kata kunci: Selulase, isolat bakteri, larva Cossus cossus.

\begin{abstract}
Industrial and agricultural wastes containing cellulose has the potential as an alternative fuel, especially rice straw. This study was conducted to test the $\mathrm{CC} 1$ and $\mathrm{CC} 4$ hydrolysis of bacterial isolates from the gut of wood-eating larvae Cossus cossus using rice strawlig no cellulose and cellulose that has been removed lignin by chemical mean sand unprocessed rice straw. Measurement of cellulose enzyme activity using UV-VIS spectrophotometer at the optimum temperature and $\mathrm{pH}$ predetermined. By using the method of Nelson Somoghy obtained the highest activity in the cellulase enzymes hydrolyze the substrate on cellulose powder with optimum activity at $\mathrm{pH} 4 \mathrm{CC} 4$ isolates of $2.775 \times 10^{-2} \mathrm{U} / \mathrm{mL}$, while the enzyme activity $\mathrm{CC} 2$ isolates $4.359 \times 10^{-2} \mathrm{U} / \mathrm{mL}$, this occurs due to the enzymatic hydrolysis of cellulosic substrates with cellulase enzymes will outline the cellulose into glucose which is a simple form.
\end{abstract}

Keywords : bacterial isolates, cellulase, , larvae of Cossus cossus.

\section{PENDAHULUAN}

Berdasarkanprogram pemerintah dalam mencari energi alternatif pengganti minyak bumi, maka berbagai cara telah dilakukan dan salah satunya adalah produksi bioetanol. Bioetanol dapat diproduksi dari berbagai bahan seperti bagas dan jerami. Limbah industri dan pertanian diantaranya limbah dari pabrik gula, tandan kelapa sawit, kayu dan batang pisang. Bahan-bahan limbah tersebut memiliki kandungan lignoselulosa yang melimpah, namun belum digunakan secara maksimal. Pemanfaatan lignoselulosa untuk produksi bioetanol dapat menjadi pertimbangan karena tidak bersaing dengan kebutuhan pangan (Trisanti 2009).

Namun, penggunaannya sebagai bahan baku perlu proses delignifikasi. Proses ini mampu menghilangkan sebagian lignin dan hemiselulosa yang melindungi molekul selulosa. Pada saat yang bersamaan terjadi pemutusan ikatan hidrogen terutama ikatan 
intermolekul selulosa.Akhirnya terbentuk selulosa dalam keadaan tidak terikat. Keadaan ini menyebabkan selulosa menjadi longgar ikatannya dengan komponen non-selulosa maupun pada selulosanya sendiri.Dengan demikian, enzim selulase dapat lebih mudah kontak dengan selulosa dan mempermudah hidrolisis selulosa menjadi gula-gula sederhana.

Penggunaan enzim selulase pada proses ini karena telah umum digunakan untuk berbagai keperluan. Selulase dapat diaplikasikan dalam industri kertas, tekstil, makanan, dan detergen.Selain itu, enzim ini digunakan untuk meningkatkan kualitas nutrisi pakan ternak dan berperan penting dalam biokonversi selulosa menjadi berbagai komoditas senyawa kimia.Enzim selulase ini dapat diproduksi oleh fungi, bakteri serta mikroorganisme.Mikroorganisme penghasil selulase dari kelompok bakteri memiliki tingkat pertumbuhan yang cepat sehingga waktu yang dibutuhkan untuk memproduksi selulase menjadi lebih pendek.

Bakteri selulolitik menghasilkan enzim secara induktif, yaitu enzim yang dihasilkan karena adanya induktor dari senyawa kimia tertentu dalam media produksinya.Salah satu contoh enzim induktif yaitu enzim yang dihasilkan di dalam media pertumbuhan hanya ada selulosa sebagai satu-satunya sumber karbon. Kondisi ini akan menginduksi mikroorganisme menghasilkan selulase agar dapat menghidrolisis selulosa menjadi glukosa. Glukosa merupakan gula sederhana yang dapat langsung digunakan tanpa harus didegradasi terlebih dahulu sebagai sumber karbon untuk memasuki jalur glikolisis dalam proses metabolismenya. Akibatnya pembelahan sel berlangsung dengan cepat dan jumlah sel bertambah banyak sehingga konsentrasi enzim akan meningkat dan aktivitas enzim makin besar.

Larva Cossus cossusmerupakan salah satu serangga yang mampu menghasilkan enzim selulase yang menggunakan pohon sebagai tempat hidup dan makanannya. Larva ini memiliki karakteristik yang mencerminkan cara hidup mereka, mengebor pada kayu dan batang. Kepala besar, lebih panjang dan lebar dengan rahang besar.Prothorax berbentuk seperti plat yang khas atau perisai yang memiliki ekor margin halus (Southdene 1986).

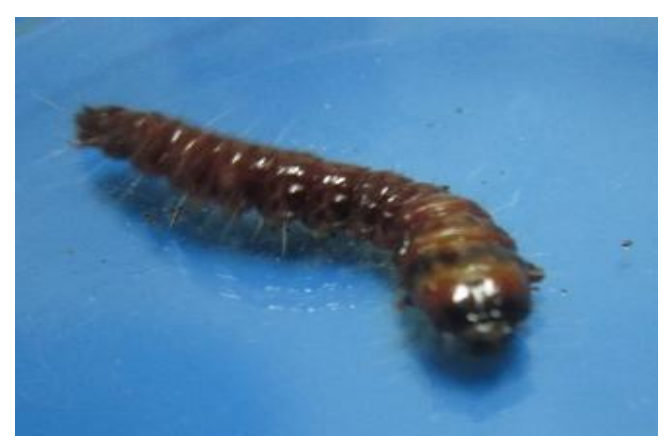

Gambar 1. Larva Coccus coccus

Berdasarkan hal tersebut diatas, maka dilakukan penelitian tentang potensi enzim selulase dari isolat bakteri larva Cossus cossus dalam hidrolisisjerami padi.

\section{METODE PENELITIAN}

\section{Isolasi Lignoselulosa dan Selulosa dari Jerami Padi}

Isolasi lignoselulosa dari jerami dilakukan dengan terlebih dahulu mengeringkan jerami yang akan digunakan sampai ukuran 40 mesh. Jerami padi yang telah diayak kemudian dicuci dengan akuades. Campuran disaring, residu selanjutnya dikeringkan dalam oven pada suhu $50^{\circ} \mathrm{C}$. Setelah itu ditambahkan $\mathrm{HCl} 3 \%$ untuk melarutkan mineral-mineral yang terkandung di dalam jerami padi. Kemudian disaring, dan residunya dicuci dengan akuades sampai $\mathrm{pH}$ netral (uji dengan lakmus) selanjutnya dikeringkan dalam oven. Sedangkan untuk Isolasi selulosa dilakukan dengan menambahkan larutan $\mathrm{NaOCl} 10 \%$ kedalam serbuk lignoselulosa, kemudian dilakukan maserasi selama 24 jam.Kemudian campuran disaring dan endapannya dicuci dengan 
akuades sampai $\mathrm{pH}$ netral (uji dengan lakmus), dikeringkan didalam oven dan ditimbang bobotnya.Selanjutnya dilakukan penentuan kadar lignoselulosa dan selulosa dari jerami padi menggunakan metode (SNI 01-13031989).

\section{Produksi Enzim Selulase}

Isolat bakteri selulolitik diinokulasikan sebanyak 2 ose dalam $200 \mathrm{ml}$ media CMC Broth $1 \%$ ( 1 gram CMC, $\mathrm{K}_{2} \mathrm{HPO}_{4} 0.1$ gram, $\mathrm{CaCl}_{2} .2 \mathrm{H}_{2} \mathrm{O} 0.04$ gram, $\mathrm{MgSO}_{4} 7 \mathrm{H}_{2} \mathrm{O} 0.04$ gram, yeast extract 0.4 gram ) diinkubasi pada shaker inkubator pada suhu $50^{\circ} \mathrm{C}$ hingga fase eksponensial. Selanjutnya enzim kasar yang diperoleh di sentrifugasi pada kecepatan 3000 rpm selama 15 menit pada suhu $4^{\circ} \mathrm{C}$.

\section{Aktivitas Selulase pada substrat Jerami Padi}

Sebanyak 0.05 gram substrat lignoselulosa, selulosa, dan serbuk jerami ditambahkan $5 \mathrm{ml}$ buffer dan $5 \mathrm{ml}$ enzim ekstrak kasar. Reaksi antara substrat dan enzim ekstrak kasar dilakukan dalam erlemeyer 100 $\mathrm{ml}$ selama 60 menit pada suhu optimum. Setelah itu reaksi dihentikan

\section{HASIL DAN PEMBAHASAN}

\section{Kadar Lignoseulosa, Selulosa dari Jerami Padi}

Berdarkan penentuan kadar yang dilakukan (SNI 01-1303-1989), didapatkan kadar lignoselulosa pada jerami padi yakni $22.8698 \%$ sedangkan kadar selulosa pada jerami yaitu $31.9813 \%$.

\section{Hidrolisis Lignoselulosa, Selulosa, Serbuk Jerami}

Berdasarkan hidrolisis substrat (serbuk lignoselulosa, serbuk selulosa, dan serbuk jerami ) menggunakan Isolat $\mathrm{CC} 2$ dan $\mathrm{CC} 4$ pada $\mathrm{pH} 7.5$ dan 4 (berdasarkan pengujian $\mathrm{pH}$ optimum) diperoleh aktivitas enzim pada $\lambda$ maks 545 adalah sebagai berikut:
Tabel 1 Data hasil hidrolisis substrat menggunakan enzim selulase dari Isolat $\mathrm{CC} 2$ pada $\mathrm{pH} 7.5$

\begin{tabular}{lc}
\hline \multicolumn{1}{c}{ Substrat } & Aktivitas Enzim $(\mathrm{U} / \mathrm{mL})$ \\
\hline Lignoselulosa & $24.25 \times 10^{-3}$ \\
Selulosa & $24.25 \times 10^{-3}$ \\
Serbuk jerami & $20.37 \times 10^{-3}$ \\
\hline
\end{tabular}

Tabel 2 Data hasil hidrolisis substrat menggunakan enzim selulase dari Isolat $\mathrm{CC} 2$ pada $\mathrm{pH} 4$

\begin{tabular}{lc}
\hline \multicolumn{1}{c}{ Substrat } & Aktivitas Enzim $(\mathrm{U} / \mathrm{mL})$ \\
\hline Lignoselulosa & $20.75 \times 10^{-3}$ \\
Selulosa & $27.75 \times 10^{-3}$ \\
Serbuk & $16.16 \times 10^{-3}$ \\
jerami & \\
\hline
\end{tabular}

Tabel 3 Data hasil hidrolisis substrat menggunakan enzim selulase dari Isolat $\mathrm{CC} 4$ pada $\mathrm{pH} 7.5$

\begin{tabular}{lc}
\hline \multicolumn{1}{c}{ Substrat } & Aktivitas Enzim $(\mathrm{U} / \mathrm{mL})$ \\
\hline Lignoselulosa & $10.65 \times 10^{-3}$ \\
Selulosa & $15.02 \times 10^{-3}$ \\
Serbuk jerami & $9.129 \times 10^{-3}$ \\
\hline
\end{tabular}

Tabel 4 Data hasil hidrolisis substratmenggunakan enzim selulase dari Isolat $\mathrm{CC} 4$ pada $\mathrm{pH} 4$

\begin{tabular}{lc}
\hline \multicolumn{1}{c}{ Substrat } & Aktivitas Enzim $(\mathrm{U} / \mathrm{mL})$ \\
\hline Lignoselulosa & $42.95 \times 10^{-3}$ \\
Selulosa & $43.59 \times 10^{-3}$ \\
Serbuk jerami & $35.76 \times 10^{-3}$ \\
\hline
\end{tabular}

Jerami memiliki kandungan serat kasar yang cukup tinggi, berdasarkan penelitian yang dilakukan oleh Larasati (2012) mengenai analisis serat kasar pada jerami padi, didapatkan bahwa didalam jerami padi terdapat $57.04 \%$ serat kasar. Tahap isolasi selulosa dilakukan dengan mencampurkan sebanyak 11.8519 gram serbuk lignoselulosa dengan larutan natrium hipoklorit $(\mathrm{NaOCl}) \quad 10 \%$ selama 24 jam.Penggunaan konsentrasi larutan natrium hipoklorit $(\mathrm{NaOCl})$ yang digunakan adalah 10\%, ditentukan berdasarkan banyaknya lignin yang dapat diurai.Hal ini berkaitan dengan penentuan konsentrasi larutan natrium hipoklorit $(\mathrm{NaOCl})$ untuk delignifikasi. Semakin tinggi konsentrasi natrium hipoklorit $(\mathrm{NaOCl})$ maka semakin banyak pula lignin yang mampu diurai, 
konsentrasi maksimum yang digunakan adalah $10 \%$ karena jika konsentrasi natrium hipoklorit ( $\mathrm{NaOCl})$ yang digunakan lebih dari $10 \%$ akan merusak xilan yang berstruktur amorf. Proses ini dilakukan untuk membuka struktur lignoselulosa agar selulosa menjadi lebih mudah diakses oleh enzim yang memecah polimer polisakarida menjadi monomer gula.

Berdasarkan penentuan kadar lignoselulosa, selulosa dan lignin pada serbuk jerami dengan metode SNI, didapatkan kadar lignoselulosa pada jerami padi yakni $22.8698 \%$, hasil ini mendekati kadar lignoselulosa pada jerami padi bersarkan komposisi kimia bahan mentah dan stimulasi produksi etanol yaitu sebesar $23 \%$ sedangkan pada kadar selulosa jerami padi didapatkan sebesar $31.9813 \%$, sedangkan berdasarkan pada komposisi kimia bahan mentah dan stimulasi produksi etanol kadar selulosa pada jerami padi sebesar $32 \%$.

Pada penentuan kadar lignin didapatkan diperoleh kadar lignin sebesar $12.2788 \%$. Hasil ini sangat rendah bila dibandingkan dengan hasil pada penelitian yang dilakukan oleh Larasati (2012), yang mendapakan kadar lignin pada jerami padi yakni sebesar $32.07 \%$, namun hasil dari penelitian ini mendekati nilai kadar lignin berdasarkan komposisi kimia bahan mentah dan stimulasi produksi etanol yakni sebesar 13\%. Kadar ini menunjukkan besarnya lignin yang ada pada jerami padi sehingga harus dilakukan penghilangan lignin, karena lignin menghambat proses hidrolisis selulosa. Kadar lignin yang tinggi memperkecil akses enzim terhadap substrat yang menyebabkan rendahnya aktivitas enzim dalam menghidrolisis substrat.

Berdasarkan hasil pengukuran aktivitas enzim terhadap substrat menggunakan Spektrofotometer UV-VIS (Tabel 1 dan 2) untuk isolat CC2 dan (Tabel 3 dan 4) untuk isolat CC4, diketahui bahwa penggunaan serbuk jerami dan serbuk lignoselulosa sebagai substrat dalam hidrolisis menggunakan enzim selulase kurang efisien, ini dibuktikan pada aktivitas enzim yang sangat rendah yakni $9.12 \times 10^{-3} \mathrm{U} / \mathrm{mL}$ pada serbuk jerami, hal ini karena serbuk jerami dan serbuk lignoselulosa masih terikat dengan lignin, dimana lignin dapat menghambat proses hidrolisis enzim. Semakin rendah kadar selulosa yang ada pada substrat maka semakin kecil kemungkinan sisi aktif enzim berikatan dengan substrat, hal ini disebabkan mulai habisnya nutrisi yang tersedia sehingga pertumbuhan sel dan produksi enzim terhenti.

Dengan demikian aktivitas tertinggi enzim selulase dalam menghidrolisis substrat pada $\mathrm{pH}$ optimum berlangsung pada substrat selulosa. Hidrolisis yang terjadi secara enzimatik pada substrat selulosa dengan enzim selulase akan menguraikan selulosa menjadi bentuk yang sederhana antara lain selobiosa dan glukosa.

Aktivitas enzim juga disebabkan pada suhu yang digunakan.Pada penelitian ini digunakan suhu $50{ }^{\circ} \mathrm{C}$ sebagai suhu optimum untuk menentukan aktivitas tertinggi enzim selulase dalam menghidrolisis substrat.

Penggunaan suhu optimum digunakan untuk mengoptimalkan kerja enzim selulase. Hal ini berarti bahwa ketika enzim berada pada suhu diatas $50{ }^{\circ} \mathrm{C}$ akan mengalami kerusakan (denaturasi), namun ketika enzim berada pada suhu dibawah $50{ }^{\circ} \mathrm{C}$, enzim belum aktif.

Berdasarkan penelitian yang telah dilakukan, didapatkan aktivitas terbaik enzim selulase dalam menghidrolisis substrat (serbuk jerami, serbuk lignoselulosa, dan serbuk selulosa) yakni pada substrat serbuk selulosa. Hal ini dilihat pada aktivitas enzim setelah diukur dengan Spektrofotometer UV-VIS, untuk Isolat CC4 memiliki aktivitas tertinggi pada selulosa sebesar $4.359 \times 10^{-2} \mathrm{U} / \mathrm{mL}$ sama halnya pada isolat $\mathrm{CC} 2$ memiliki aktivitas $2.425 \times 10^{-2} \mathrm{U} / \mathrm{mL}$, hal ini ini disebabkan karena enzim yang digunakan adalah enzim selulase yang merupakan enzim yang dapat menghidrolisis selulosa. Dan selulosa yang digunakan adalah selulosa murni.

Selain itu, pada substrat serbuk lignoselulosa didapatkan aktivitas enzim isolat 
CC4 sebesar $4.295 \times 10^{-2} \mathrm{U} / \mathrm{mL}$ dan pada isolat CC2 serbuk lignoselulosa yaitu $2.07 \times 10^{-2}$ $\mathrm{U} / \mathrm{mL}$. Bila dibandingkan serbuk jerami untuk isolat CC4 $3.57 \times 10^{-2} \mathrm{U} / \mathrm{ml}$ dan untuk isolat CC2 $1.61 \times 10^{-2}$.

Besarnya aktivitas enzim pada lignoselulosa dibandingkan pada serbuk jerami jerami disebabkan karena substrat lignoselulosa telah mengalami penghilangan mineral mineral sehingga sebahagian dapat dihidrolisis oleh enzim selulosa.Pada lignoselulosa dan serbuk jerami memiliki aktivitas enzim yang lebih rendah, hal ini karena pada kedua substrat tersebut sebagian komponen pembentuk yakni berupa selulosa dan lignin.Dimana, lignin membungkus dan mengikat selulosa secara fisik sehingga menghalangi enzim selulase bekerja maksimal untuk melakukan hidrolisis pada substrat (Anja 2009).

Analisis aktivitas enzim juga dapat dilakukan secara kualitatif, hal ini dapat dilihat pada penelitian yang telah dilakukan oleh Jonathan (2014), yang menganalisis aktivitas enzim terhadap glukosa yang ada didalam sukun secara kualitatif dengan menggunakan uji benedict.Dimana sampel menunjukkan hasil positif dengan terbentuknya endapan merah bata, hasil ini menunjukkan bahwa enzim bekerja menghidrolisis pati pada sukun.

\section{SIMPULAN}

Proses isolasi lignoselulosa dari jerami padi dapat dilakukan menggunakan asam klorida $(\mathrm{HCl})$ dan didapatkan kadar lignoselulosa yakni 20.2\%.Proses isolasi selulosa dari jerami padi dilakukan menggunakan larutan natrium hipoklorit (NaOCl) $10 \%$ dan didapatkan kadar selulosa yakni $32 \%$.

Hidrolisis substrat dengan menggunakan enzim ekstrak kasar pada $\mathrm{pH}$ dan suhu optimum menghasilkan aktivitas tertinggi pada selulosa. pada serbuk selulosa dengan aktivitas optimum isolat $\mathrm{CC} 4$ pada $\mathrm{pH}$ 4 sebesar $2.775 \times 10^{-2} \mathrm{U} / \mathrm{mL}$ sedangkan pada isolat CC2 aktivitas enzim $4.359 \times 10^{-2} \mathrm{U} / \mathrm{mL}$, hal ini karena hidrolisis yang terjadi secara enzimatik pada substrat selulosa dengan enzim selulase akan menguraikan selulosa menjadi bentuk yang sederhana yakni glukosa.

\section{Daftar Pustaka}

Anindyawati Trisanti. 2009. Prosepek Enzim dan Limbah Lignoselulosa untuk Produksi Bioetanol.Serpong (ID): Pusat Penelitian Bioteknologi-LIPI.

Karakterisasi dan Identifikasi Bakteri Termofilik Amilolitik dengan Menggunakan Metode Fenotifik dan Metode Molekuler Gen Parsial 16S rRN.2010. [Skripsi]. Bandung (ID): Universitas Pendidikan Indonesia

BintangMaria. 2010. Biokimia Teknik Penelitian. Jakarta (ID): Erlangga.

Budiman Albar, Sigit Setyawan. 2011. Pengaruh Konsentrasi Substrat, Lama Inkubasi dan $\mathrm{pH}$ dalam Proses Isolasi Enzim Xylase dengan Menggunakan Media Jerami Padi. [Skripsi].Semarang (ID): Fakultas Teknik Universitas Diponegoro.

Departemen Agama Republik Indonesia. 2002. AlQur'an dan Terjemahnya. Jakarta (ID): Darus Sunnah.

Dewi IM. Isolasi Bakteri dan Uji Aktivitas Kitinase Termofilik Kasar dari Sumber Air Panas Tinggi Raja, Sumalungun Sumatera Utara.[Tesis]. Medan (ID): Universitas Sumatera Utara.

Ginting Jusuf. 2009. Isolasi Bakteri dan Uji Aktifitas Enzim Amilase Kasar Termofilik dari Sumber Air Panas Semangat Gunung Kabupaten Karo Sumatra Utara.[Tesis]. Medan (ID): Universitas Sumatera Utara.

Hartanti. 2010. Isolasi dan Seleksi Bakteri Selulolitik Termofilik dari Kawah Air Panas Gunung Pancar.[Skripsi]. Bogor (ID): Fakultas Matematika dan Ilmu Pengetahuan Alam Institut Pertanian Bogor.

Harunsyah, Ridwan. 2014. Pengaruh perlakuan awal biomassa jerami padi untuk merecoveri gula reduksi dengan metode hidrolisa secara enzimatik. Jurnal Politeknik Negeri Lhokseumawe: h. 1-9.

Hermiati, Euis., dkk. "Pemanfaatan Biomassa Lignoselulosa Ampas Tebu untuk Produksi Bioetanol". Bogor: Fakultas Teknologi Pertanian IPB, 2010. 
IriantoKoes. 2006. Mikrobiologi: Menguak Dunia Mikroorganisme. Bandung (ID): Yrama Widya.

Kamila Laila. Pencirian Selulolitik Isolat khamir Rhodotorula sp. dari Tanah Hutan Tanaman Nasional Gunung Halimun.[Skripsi]. Bogor (ID): Fakultas Matematika dan Ilmu Pengetahuan Alam Institut Pertanian Bogor.

LarasatiRaissa. 2012. Sintesis Fase Diam Selulosag-AAM dengan Berbagai Kadar PenautSilang sebagai Media Separator Xantorizol dari Ekstrak Temu Lawak. [Skripsi]. Bogor (ID): Departeman Kimia Fakultas Matematika dan Ilmu Pengetahuan Alam Institut Pertanian Bogor.

Melwita Elda. 2011. Ionic Liquid sebagai Katalisator Potensial untuk Meningkatkan Produksi Biofuel.[Skripsi]. Palembang (ID): Fakultas Teknik Universitas Sriwijaya.

Merina F, Yulinah T.2011. Produksi Bioetanol dari Eceng Gondok (Eichhornia crassipes) dengan Zymomonas mobilis dan Saccharomyces cerevisiae.[Tesis].Surabaya Pascasarjana Institut Teknologi Sepuluh November.

Mushoffa.2012. Isolasi dan Identifikasi Bakteri Selulolitik dari Feses Kambing.[Skripsi]. Malang (ID): Fakultas Sains dan Teknologi UIN Maulana Malik Ibrahim.

Novia, "Hidrolisis Enzimatik dari Fermentasi TKKS yangDidelignifikasi dengan Asam Sulfat dan $\mathrm{NaOH}$ untuk Memproduksi Etanol". Palembang: Fakultas Teknik Universitas Sriwijaya, 2011.

NurhalijahS. 2008. Isolasi Bakteri dan Uji Aktivitas Amilase Kasar Termofilik dari Sumber Air Panas Gurokinayan Karo Sumatera Utara.[Tesis]. Medan (ID): Universitas Sumatera Utara.

Pakpahan R. 2009. Isolasi Bakteri dan Uji Aktivitas Protoase Termofilik dari Sumber Air
Panas Sipohon Tapanuli Utara Sumatera Utara.[Tesis]. Medan (ID): Universitas Sumatera Utara.

Purnawan.2011. Pemanfaatan Limbah Serat Industri Tepung Sagu Aren sebagai Bahan Baku Pembuatan Kertas (Pulp) dengan Proses Delignifikasi.[Skripsi].Yogyakarta (ID): Fakultas Sains dan Teknologi AKPRIND.

RahmiFLA, Dahliaty,SDevi.2014. Optimalisasi Komposisi Media dan Konsentrasi Sumber Karbon Produksi Enzim Selulase Bakteri Selulolitik Strain Lokal S-16 dan S22.Jurnal Binawidya Pekanbaru: 1-9.

Saropah DA, Akyunul J, Anik M. 2012.Kinetika Reaksi Enzimatis Ekstrak Kasar Enzim Selulase Bakteri Selulolitik Hasil Isolasi dari Bekatul.Jurnal Kimia. 2(1):

Sianturi DC. 2008. Isolasi Bakteri dan Uji Aktivitas Amilase Termofil Kasar dari Sumber Air Panas Penen Sibirubiru Sumatera Utara.[Tesisi]. Medan (ID): Universitas Sumatera Utara.

Standar Nasional Indonesia.2008.Cara Uji Kadar Lignin 0492-2008. Jakarta (ID): Badan Standar Nasional.

Standar Nasional Indonesia. 2009. Cara Uji Kadar Selulosa, $\alpha$-selulosa, $\beta$-selulosa dan $\gamma$ selulosa 0444-2009. Jakarta (ID): Badan Standar Nasional.

Wahyuni V. 2001.Aktivitas Selulase Bacillus pumilus Galur 55 yang Diisolasi dari Sumber Air Panas.[Skripsi]. Bogor (ID): Fakultas Matematika dan Ilmu Pengetahuan Alam IPB.

Wayan IB, Ketut B, I Made Y. 2010. Pengaruh Perlakuan Delignifikasi dengan Larutan $\mathrm{NaOH}$ dan Konsentrasi Substrat Jerami Padi Terhadap Produksi Enzim Selulase dari Aspergillus niger NRRL A-II 264. Jurnal Biologi.XIV(2): 55-61. 